6. О безопасности: федеральный закон от 28 декабря 2010 г. № 390-Ф3 (последняя редакция) // Система КонсультантПлюс [Электронный ресурс] - Режим доступа: http://www.consultant.ru/document/cons_doc_LAW_108546/\#dst0, яз. pус.

7. Концепция внешней политики Российской Федерации: утверждена Указом Президента Российской Федерации от 30 ноября 2016 года № 640 - Режим доступа: http://docs.cntd.ru/document/420384312.

\title{
Салихова А.A.
}

\section{Проблемы института признания гражданина безвестно отсутствующим и перспективы его реформирования}

Стерлитамакский филиал БашГУ

(Россия, Стерлитамак)

doi: $10.18411 / s r-10-06-2021-34$

\section{Аннотация}

В данной научной статье рассматриваются проблемы института признания гражданина безвестно отсутствующим.

Автором статьи делается попытка раскрыть особенности и перспективы его реформирования.

В статье раскрыта суть проблемы института признания гражданина безвестно отсутствующим, а так же отмечается, что институт признания гражданина безвестно отсутствующим преследует целью защитить права граждан в связи с прерыванием тех гражданских правоотношений, участниками которых они являются.

Автор статьи обращает внимание на то, что правовое регулирование гражданских отношений предполагает участие гражданина в правоотношениях. С помощью норм, входящих в этот институт, заинтересованные лица могут обратиться в соответствующие государственные органы и добиться устранения неопределённости в правовых отношениях, участником которых значится соответствующее лицо, либо, во всяком случае, свести к минимуму отрицательные последствия такой неопределённости.

Ключевые слова: гражданин, правоотношения, институт, право, безвестно отсутствующий, суд, Совет, комитет, попечительство.

\footnotetext{
Abstract

This scientific article examines the problems of the institution of recognition of a citizen as missing.

The author of the article makes an attempt to reveal the features and prospects of its reform.

The article reveals the essence of the problem of the institution of recognizing a citizen as missing, and also notes that the institution of recognizing a citizen as missing is aimed at protecting the rights of citizens in connection with the interruption of those civil relations in which they are participants.

The author of the article draws attention to the fact that the legal regulation of civil relations involves the participation of a citizen in legal relations. With the help of the norms included in this institution, interested parties can contact the relevant state bodies and achieve the elimination of uncertainty in legal relations to which the relevant person is listed, or, in any case, minimize the negative consequences of such uncertainty.

Keywords: citizen, legal relationship, institution, law, missing person, court, council, committee, guardianship.
} 
Возможность признания гражданина безвестно отсутствующим предназначена для регулирования правоотношений, складывающихся в период длительного отсутствия субъекта правоотношений или сведений о его местонахождении.

Институт признания гражданина безвестно отсутствующим направлен на защиту прав граждан, связанных с нарушением гражданских отношений, в которые они вовлечены. [4, с. 17]

В юридической практике широко распространены ситуации, когда для устранения неопределенностей в гражданско-правовых отношениях приходится прибегать к возможности признания гражданина безвестно отсутствующим или объявления его умершим.

С помощью норм, содержащихся в этих учреждениях, заинтересованные стороны могут связаться с соответствующими государственными органами и добиться устранения неопределенностей в правовых отношениях, в которых указано заинтересованное лицо, или в любом случае минимизировать негативные последствия этой неопределенности. [5, с. 105]

Безвестное отсутствие - это особое юридическое условие; факт длительного отсутствия гражданина по месту жительства, подтвержденный судом при невозможности определения его места жительства. [6, с. 65]

Согласно п.1 ст. и ст. 42 ГК РФ, гражданин по ходатайству заинтересованных лиц может быть признан судом безвестно отсутствующим, если в течение года отсутствуют сведения о его месте жительства по месту жительства. [2, с. 34]

Правовое регулирование гражданских отношений включает участие гражданина в правоотношениях. Однако возможны ситуации, когда информация о гражданине по постоянному месту жительства отсутствует длительное время. Возникает ситуация, когда есть неопределенность в сфере гражданско-правовых отношений.

Такая ситуация влияет на нормальное развитие гражданских отношений с участием такого гражданина, затрагивает права и законные интересы других лиц. [7, с. 96]

С одной стороны, это довольно специфично, с другой - увидеть невозможно. Чтобы избежать такой неопределенности, которая нежелательна во всех отношениях, законом предусмотрены особые правила, которые вместе образуют институт неизвестного отсутствия.

Роль и значение объекта неизвестного отсутствия резко возрастают в экстремальных ситуациях, таких как военные действия или стихийные бедствия. Чтобы снять неопределенность в гражданских отношениях и защитить права и интересы других лиц, необходимо обратиться в институт неизвестного отсутствия. [7, с. 75]

Признание гражданина пропавшим без вести в первую очередь направлено на защиту прав самого пропавшего без вести гражданина и тех, с кем он состоит в семейных и гражданских отношениях.

Неизвестным отсутствием считается установленный в суде факт длительного отсутствия гражданина по месту постоянного жительства. [4, с. 76]

Гражданин признается безвестно отсутствующим только по решению суда. Суд рассматривает вопрос о признании гражданина безвестно отсутствующим по запросу заинтересованных лиц в особом порядке с участием прокурора.

Если невозможно определить день получения последней информации об отсутствии, началом исчисления срока обнаружения неизвестного отсутствия считается первый день месяца, следующего за днем, когда появилась последняя информация об отсутствии. получено отсутствие, а если невозможно установить в этом месяце - первое января следующего года. [6, с. 43]

Решение о признании гражданина безвестно отсутствующим принимается судом в особом порядке. Принимая решение, суд оценивает все имеющиеся факты, которые могут повлиять на решение. Следовательно, гражданские отношения предназначены 
для их нормального развития и не подразумевают, что кто-либо может намеренно скрыть и уклониться от обнаружения своего местонахождения.

На основании решения суда о признании гражданина безвестно отсутствующим Совет опеки и попечительства передает имущество отсутствующего гражданина в доверительное управление лицу, назначенному этим советом. [7, с. 23]

Имущество без вести пропавшего используется для выплаты алиментов гражданам, которых пропавшее лицо обязано содержать, а также погашаются долги по другим их обязательствам. Вместе с функцией управления имуществом неизвестное отсутствие может иметь другие предусмотренные законом последствия. Например, в упрощенном порядке можно расторгнуть брак с пропавшим без вести. [4, с. 98]

Если имущество гражданина имеет такой характер, что требует постоянного управления, Совет по опеке и попечительству может назначить управляющего имуществом отсутствующего гражданина до окончания годичного срока.

При этом выплаты по имуществу производиться не будут, пока суд не примет решение о признании гражданина безвестно отсутствующим.

В случае явки или установления местонахождения отсутствующего гражданина суд отменяет решение о признании его безвестно отсутствующим и, соответственно, управление его имуществом приостанавливается.

Основные правовые последствия признания гражданина безвестно отсутствующим заключаются в следующем.

Во-первых, если требуется постоянное управление, имущество такого гражданина передается в доверительное управление. В соответствии с решением суда о передаче имущества в доверительное управление Совет по опеке и попечительству назначит управляющего и заключает с ним договор об управлении условным депонированием. [6, с. 97]

Именно за счет этого имущества поддерживаются граждане, которых пропавший без вести обязан содержать, а также выплачиваются долги по другим обязательствам пропавшего без вести.

Закон допускает назначение управляющего имуществом отсутствующего гражданина даже раньше, чем через год со дня получения информации о месте его пребывания. В этом случае администратор назначается Управлением опеки и попечительства по собственному усмотрению без обращения в суд.

Управляющий передает средства гражданам, которых пропавший без вести обязан содержать по закону (несовершеннолетним детям, родителям-инвалидам и т. д.), а также погашает его долги по другим обязательствам.

По просьбе заинтересованных лиц Комитет по опеке и попечительству может назначить опекуна для защиты имущества гражданина, если гражданин отсутствовал менее года и не был признан безвестно отсутствующим. Однако по закону в этом случае опекун назначается только для защиты имущества и не может производить с него выплаты. [5, с. 105]

Во-вторых, если гражданин признан безвестно отсутствующим в отношении находящихся на его иждивении нетрудоспособных членов семьи, то право на пенсию по случаю потери кормильца возникает в соответствии с правилами пенсионного законодательства.

В-третьих, согласно статье 188 Гражданского кодекса, доверенность, выданная на имя пропавшего без вести и выданная им самим, прекращается.

В-четвертых, супруга гражданина, признанного безвестно отсутствующим, имеет право на расторжение брака в упрощенном порядке через ЗАГС. В случае явки или установления местонахождения гражданина, признанного безвестно отсутствующим, суд отменяет решение о признании безвестно отсутствующим. [5, с. 87] 
Решением суда доверительное управление имуществом гражданина прекращается, а иные правоотношения, возникшие в результате признания безвестно отсутствующим, прекращаются.

Если гражданин окажется пропавшим без вести, его смерти не ожидается. В анализируемой статье предлагаются две причины отмены решения суда о признании гражданина безвестно отсутствующим:

1) его явку,

2) обнаружение места его пребывания. [5, с. 29]

И сам гражданин, и лицо, по инициативе которого было решено дело о признании гражданина безвестно отсутствующим, с заявлением об отмене решения суда. Новое определение суда является основанием для отмены опеки над имуществом гражданина и прекращения иных правоотношений, возникших в связи с признанием его безвестного отсутствия.

В случае развода он может быть восстановлен в ЗАГСе по совместному заявлению супругов. Брак не может быть восстановлен, если другой супруг повторно женится.

В случае явки или обнаружения места жительства гражданина все правовые последствия, связанные с судьбой его имущества и признанием его безвестно отсутствующим по решению суда, снимаются.

Гражданин может быть объявлен судом умершим, если нет сведений о его месте жительства по месту жительства в течение пяти лет и он исчез при обстоятельствах, угрожающих смертью или дающих основания полагать, что он умер в результате конкретного несчастного случая, - в течение шести месяцев. [7, с. 88]

Лица, которым имущество гражданина, объявленного умершим, было передано в рамках компенсационных сделок, обязаны вернуть ему это имущество, если будет доказано, что они знали при покупке имущества, что гражданин, объявленный умершим, жив. [5, с. 65]

В случае невозможности вернуть такое имущество в натуре, его стоимость будет возвращена.

Признание граждан пропавшими без вести - это не что иное, как определение определенных обстоятельств, позволяющих сделать вывод о том, что местонахождение гражданина неизвестно и что существуют определенные правовые последствия для заинтересованных лиц.

Несмотря на то, что это учреждение является институтом гражданского права, факт неизвестного отсутствия имеет более широкое значение, поскольку нарушает не только гражданско-правовые отношения, но и отношения, регулируемые другими отраслями права.

Такие дисциплины, как семейное и уголовное право, рассматривают такое сложное явление корпоративного права, как признание гражданина пропавшим без вести. Прерваны трудовые отношения, отношения с обеспечением по старости.

Анализируя юридическое определение понятий «место жительства» и «место жительства», исследователь сталкивается с тем, что в действующем законодательстве нет единого определения места жительства и места жительства.

Расследование судами практики рассмотрения соответствующей категории дел показало, что заявитель по данной категории дел и другие заинтересованные лица часто не информируются о нахождении лица в местах лишения свободы. [4, с. 17]

Следовательно, пропавшим без вести должен быть человек, местонахождение которого можно надежно определить. Кроме того, в правовых актах Российской Федерации отсутствует понятие военных действий. В то же время законодатели связывают это понятие с объявлением солдата, участвовавшего в войне, мертвым, и эти и другие лазейки, противоречия и неясности в законодательстве указывают на необходимость их улучшения. [5, с. 77] 
В случае пропажи гражданина брак будет восстановлен только по совместной просьбе бывшего супруга и только в том случае, если бывший супруг не вступил в повторный брак.

При определенных обстоятельствах родительские права пропавшего без вести гражданина также могут быть прекращены «в упрощенном порядке».

Анализ норм ст. 130 СК РФ, которая предусматривает возможность усыновления несовершеннолетних детей пропавшего без вести гражданина без их согласия.

При этом правовые последствия появления гражданина после усыновления (усыновления) полностью не урегулированы. Скорее всего, законодательный орган оставил решение об отмене усыновления в каждом отдельном случае на усмотрение суда, оставив такую ситуацию в расплывчатой формулировке: по другим причинам, с учетом мнения и в интересах ребенка. [5, с. 53]

В связи с вышесказанным следует отметить, что в определенной степени можно различать конкретные субъективные права и обязанности:

- правоотношения, участие лица в которых автоматически восстанавливается в связи с явкой лица, и отмены решения суда о признании гражданина безвестно отсутствующим (например, право на пенсию для лица, появившийся);

- правовые отношения, участие в которых должно быть дополнительно восстановлено в установленном законом порядке (например, восстановление брака)

— правовые отношения, которые не подлежат восстановлению.

- примером последнего могут служить трудовые отношения, которые прекращаются независимо от того, какая из сторон трудового договора признана отсутствующей, и могут возникнуть только на основании вновь заключенного трудового договора. [7, с. 98]

Последствия признания гражданина пропавшим без вести разнообразны.

Такое признание ведет к изменению правового статуса как самого пропавшего без вести гражданина, так и других заинтересованных лиц. Эти последствия требуют обширного регулирования. Статья 3 ст. 43 ГК РФ гласит, что последствия признания лица безвестно отсутствующим, не предусмотренные настоящей статьей, устанавливаются законом. [6, с. 87]

Если таким образом законодательный орган предусмотрел принятие отдельного закона, регулирующего последствия признания лица безвестно отсутствующим, следует согласиться с этой частью позиции законодательного органа.

Согласно статье 42 Гражданского кодекса Российской Федерации суд может признать гражданина безвестно отсутствующим при отсутствии сведений о его местонахождении по постоянному месту жительства в течение года.

Признание безвестно отсутствующим возможно только судом в особом порядке и только при наличии правовой структуры, включающей:

a) длительное отсутствие лица в месте его постоянного жительства;

б) отсутствие сведений о месте его нахождения и невозможность их получения всеми доступными средствами;

в) истечение установленных законом сроков с момента получения последних известий о месте нахождения данного лица. [6, с. 22]

В пресс-центре МВД России сообщили свежие данные о розыске граждан, признанных пропавшими без вести. Так, за 2020 год розыскными подразделениями полиции было объявлено в розыск 7 тысяч 970 лиц, пропавших без вести, из них 568 несовершеннолетних. При этом местонахождение 5,2 тысячи человек из них удалось 
в течение года установить. В том числе были возвращены родителям 512 детей и подростков.

Таким образом, 2,7 тысячи человек, в том числе 56 несовершеннолетних, из безвестно исчезнувших в этом году, остаются в числе пропавших. В целом розыск пропавших без вести имеет положительную динамику. Так, количество неразысканных лиц в этом году снизилось на 3,4 процента (с учетом прошлых лет).

В России по итогам первых трех месяцев 2021 года в полицию поступило более 2 тыс. заявлений о пропаже детей, порядка 900 из них были найдены.

Проанализировав проблемные вопросы исследуемой темы, мы можем предложить следующее:

1. В статье 43 Гражданского кодекса Российской Федерации законом необходимо уточнить, какой вид имущества подлежит обязательной передаче в доверительное управление, так как это имеет большое значение, поскольку связано с определением имущества из которое должно быть выдано гражданам, находившимся на иждивении без вести пропавшего, а также для оплаты долгов по другим обязательствам без вести пропавшего.

2. В статье 44 Гражданского кодекса Российской Федерации необходимо указать правила отмены решения суда о признании гражданина безвестно отсутствующим.

3. Желательно сослаться на ст. 280 ГПК РФ, которую изложить в следующей редакции: «Явка или установление местонахождения гражданина, признанного безвестно отсутствующим, является основанием для подачи заявления. в суд самого гражданина.

В качестве безвестно отсутствующего или объявленного умершим, а также для иных заинтересованных лиц, принимавших участие в производстве, прокурор с заявлением (представлением) об отмене ранее вынесенного решения суда».

4. Представляется необходимым постановить вопрос о возможности и порядке признания гражданина безвестно отсутствующим или умершим, если этот гражданин умышленно скрывается.

$$
\text { *** }
$$

1. Конституция Российской Федерации (принята на всенародном голосовании 12 декабря 1993 г.) (в ред. от 21.07.2014) // Российская газета. 1993. 25 дек.

2. Гражданский кодекс Российской Федерации (часть первая) от 30.11.1994 г. № 51-Ф3 (в ред. от 23.05.2016 г.) // Собрание законодательства РФ. 1994. № 32. Ст. 42.

3. Гражданский процессуальный кодекс Российской Федерации от 14.11.2002 г. № 138-Ф3 (в ред. от 02.03.2016 г.) // Российская газета.2002. 20 ноября.

4. Афанасьев, И. В. Сервитут в гражданском праве: монография / И. В. Афанасьев. - М.: Издательство Юрайт, 2019. - 154 с. - (Серия : Актуальные монографии). - ISBN 978-5-534-09276-9. - Режим доступа : www.biblio-online.ru/book/1D0BB918-FB2E-4579-9DF5-C37CB89FF5A5.

5. Белов, В. А. Гражданское право. Т. 2 в 2 книгах. Общая часть. Лица, блага, факты + cd: учебник для бакалавриата и магистратуры / В. А. Белов. - 2-е изд., перераб. и доп. - М.: Издательство Юрайт, 2018. - 950 с. - (Серия: Бакалавр и магистр. Академический курс). - ISBN 978-5-9916-48813. - Режим доступа: www.biblio-online.ru/book/EF23DA33-D83A-4125-B4D4-C3B5C469F78D.

6. Белов, В. А. Гражданское право в 2 т. Том 1. Общая часть : учебник для академического бакалавриата / В. А. Белов. - М.: Издательство Юрайт, 2019. - 451 с. - (Серия : Бакалавр. Академический курс). - ISBN 978-5-534-00327-7. - Режим доступа: www.biblioonline.ru/book/4D87569A-4B4D-4F45-BF85-EBB62ECF8E30. Белов, В. А. Что изменилось в Гражданском кодексе?: практ. пособие / В. А. Белов. - 3-е изд. - М.: Издательство Юрайт, 2019. 321 с. - (Серия : Профессиональные комментарии). - ISBN 978-5-534-08128-2. - Режим доступа: www.biblio-online.ru/book/C9CC7868-0A69-417B-9669-8E0121774B26.

7. Белов, В. А. Юридические факты в гражданском праве: учеб. пособие для бакалавриата и магистратуры / В. А. Белов. - М.: Издательство Юрайт, 2019. - 450 с. - (Серия: Бакалавр и магистр. Модуль). - ISBN 978-5-534-00651-3. - Режим доступа : www.biblio-online.ru/book/96598783-6BCF435E-9025-37685677B8A7. 